FIU Law Review

Spring 2015

\title{
Commercial Purposes, Governmental Functions, and the FAA's Regulatory Authority over Unmanned Public Aircraft Operations in U.S. National Airspace
}

Douglas M. Marshall

TrueNorth Consulting LLC

Ernest E. Anderson J.D.

University of North Dakota

Follow this and additional works at: https://ecollections.law.fiu.edu/lawreview

Part of the Other Law Commons

Online ISSN: 2643-7759

Recommended Citation

Douglas M. Marshall \& Ernest E. Anderson J.D., Commercial Purposes, Governmental Functions, and the FAA's Regulatory Authority over Unmanned Public Aircraft Operations in U.S. National Airspace, 10 FIU L. Rev. 371 (2015).

DOI: https://dx.doi.org/10.25148/lawrev.10.2.6

This Article is brought to you for free and open access by eCollections. It has been accepted for inclusion in FIU Law Review by an authorized editor of eCollections. For more information, please contact lisdavis@fiu.edu. 


\title{
Commercial Purposes, Governmental Functions, and the FAA's Regulatory Authority over Unmanned Public Aircraft Operations in U.S. National Airspace
}

\author{
Douglas M. Marshall, J.D. * Ernest E. Anderson, J.D. ${ }^{* *}$
}

\section{INTRODUCTION}

On February 14, 2012, President Obama signed into law Public Law 112-95, the FAA Modernization and Reform Act of 2012 (FMRA). Subtitle B, $\S \S 331-334$, address unmanned aircraft systems, which was and is the first and only federal statutory treatment of unmanned or remotely piloted aircraft and their supporting systems. Among other provisions defining and mandating the integration of unmanned aircraft into the national airspace, $\S$ 334 of FMRA sets forth explicit guidelines for the Federal Aviation Administration (FAA) to promulgate regulations and policies dealing with civil and public unmanned aircraft systems (UAS).

A growing number of federal, state, and local governmental entities operate a wide variety of remotely piloted aircraft, ranging in size, mass, and kinetic energy, from recreational radio-controlled model airplanes to aerial surveillance or remote sensing platforms with dimensions and performance characteristics that compare to commercial passenger aircraft. More recently, a handful of law enforcement agencies have acquired small remotely piloted aircraft, or rotorcraft equipped with high-resolution cameras or remote sensing devices, and have obtained permission from the FAA to operate these devices in their jurisdictions. ${ }^{1}$

Scientists and researchers have also enjoyed the increasing availability of UAS to support their respective scientific disciplines and to collect and analyze relevant data, with a modest degree of success in obtaining necessary permissions from the controlling governmental agencies. When operated by state, local, and federal governmental entities, even very small, unmanned aerial systems are potentially subject to some degree of aviation regulation, depending upon interpretation of the statutes and regulations pertaining to these activities. The focus of this article is the uncertainty of

* Owner and founder of TrueNorth Consulting LLC, an aviation consulting company in Grand Forks, North Dakota.

**Associate Professor, University of North Dakota, Department of Aviation.

1 Benjamin Miller, Testimony at the U.S. Senate Judiciary Committee Hearing: The Future of Drones in America: Enforcement and Privacy Considerations (Mar. 30, 2013). 
the extent to which public entity UAS operations in the U.S. national airspace are subject to regulation by the FAA, and the effect that inconsistent policy pronouncements from the FAA have had on the scope of authorized remotely piloted aircraft operations. A related topic of concern to all operators of remotely piloted aircraft is the definition of "commercial UAS operations" and the enforceability of the FAA's prohibition of commercial UAS operations in light of the language of the FMRA.

\section{HISTORY OF THE POLICY}

A public aircraft is an aircraft used only by the United States government, or owned by the United States government and operated by any person for purposes of crew training, equipment development, or demonstration, or an aircraft owned and operated by the government of a State, the District of Columbia, or a territory or possession of the United States or a political subdivision of one of these governments. ${ }^{2}$ A public unmanned aircraft system is "an unmanned aircraft system that meets the qualifications and conditions required for operation of public aircraft (as defined in 49 U.S.C $\S 40102$ )." 3 The federal aviation regulations (FARs) generally do not apply to public aircraft (with some exceptions), but the FAA has declared through guidance documents and policy statements that public unmanned aircraft, their pilots/operators, and any required visual observers of unmanned aircraft systems must be certificated or meet some equivalent standard. ${ }^{4}$

Operations of all aircraft in the U.S. national airspace, including the area within three nautical miles off the coast, must comply with all relevant general operating and flight rules as set forth in the FARs. ${ }^{5}$ An "aircraft" is defined as a device that is used or intended to be used for flight in the air. ${ }^{6}$ An "airplane" is an engine-driven, fixed-wing aircraft heavier than air that is supported in flight by the dynamic reaction of the air against its wings. ${ }^{7}$ According to the FMRA, "The term 'unmanned aircraft' means an aircraft that is operated without the possibility of direct human intervention from within or on the aircraft." ${ }^{\prime 8}$ There was no regulatory or statutory definition or description of an unmanned or remotely piloted aircraft before the

2 See 49 U.S.C. $\S 40102$ (2012).

3 FAA Modernization and Reform Act of 2012, Pub. L. No. 112-95, § 331, 126 Stat. 11 (2012).

4 See Federal Aviation Administration, Unmanned Aircraft Systems, National Policy N 8900.227 (July 13, 2013).

5 See 14 C.F.R. $\S 91.1$.

614 C.F.R. $\$ 1.1$.

7 Id.

8 FAA Modernization and Reform Act of 2012, supra note 3. 
enactment of FMRA. Thus, for purposes of regulations and standards, unmanned or remotely piloted aircraft (or rotorcraft) would potentially be subject to the same set of rules and regulations as manned aircraft, unless the Administrator of the FAA specifically exempted them from regulation. The FAA created a regulatory exception by inference in an Advisory Circular (AC) $)^{9}$ issued in 1981, which declared a policy that the FARs do not apply to hobbyists and amateur model aircraft users when operating those devices for sport and recreation. ${ }^{10}$ That exemption has also been codified in FMRA. ${ }^{11}$

All pilots and essential crewmembers of U.S. civil aircraft must be properly certificated and rated for the operations flown. ${ }^{12}$ Civil aircraft operated in the U.S. National Airspace System must be airworthy and registered in the U.S., or if registered elsewhere, operated only with the permission of the FAA and air traffic controllers. ${ }^{13}$ Except as provided in 14 C.F.R. § 45.22, no person may operate a U.S.-registered aircraft unless that aircraft displays nationality and registration marks in accordance with the requirements of 14 C.F.R. $\S 45.21$, and $\S \S 45.23-45.33$. No person may operate an aircraft in the U.S. national airspace unless the aircraft is registered or is otherwise exempt from the registration requirements. ${ }^{14}$ Public aircraft are eligible for registration, but registration is not required. ${ }^{15}$

The United States Code and the rules and regulations found in the Code of Federal Regulations recognize three categories of aircraft for purposes of regulatory oversight. The first category is "state aircraft," which are defined by international civil aviation rules as aircraft operated by the military, police, and customs and border protection. ${ }^{16}$ These operations would include the use of any military aircraft, regardless of its purpose, law enforcement aviation activities, and flight operations in support of patrolling the borders or enforcement of customs and immigration laws. Generally, state aircraft of one country cannot enter the airspace of another

9 An AC is a guidance document with no regulatory effect.

10 Federal Aviation Administration, Model Aircraft Operating Standards, Advisory Circular 9157 (June 9, 1981).

11 Section 336, "Special Rules for Model Aircraft," specifically prohibits the FAA Administrator from promulgating any rule or regulation regarding a model aircraft, so long as the model aircraft meets the requirements set forth in the statute. But the Administrator is still empowered to pursue enforcement action against persons operating model aircraft who endanger the safety of the national airspace system. FAA Modernization and Reform Act of 2012, Pub. L. No. 112-95, § 336, 126 Stat. 11 (2012).

12 See 14 C.F.R. $\S 61.3$.

13 See id. $\$ 91.7$.

14 See id. $\$ 47.3$.

15 See id.

16 Convention on International Civil Aviation art. 3, Dec. 7, 1944, 61 Stat. 1180, 15 U.N.T.S. 295. 
country without that country's permission. ${ }^{17}$

The second category, "public aircraft," as designated by statute in the United States, are aircraft operated and/or owned by the federal government, or a state government, or any political subdivision thereof, so long as they are not operated commercially for compensation or hire. ${ }^{18}$ The Code of Federal Regulations offers a parallel definition of public aircraft. ${ }^{19}$ Interagency "loans" of aircraft and crew are not considered to be commercial operations so long as the individuals on the aircraft are aboard as essential crewmembers or to further the mission of the aircraft. ${ }^{20}$ For example, firefighters, researchers, scientists, and essential observers of the core activities of those individuals are typically aboard the aircraft to advance the mission of the flight, although they may not actually be piloting the aircraft. Their mere presence on the aircraft does not render the flight a civil operation. However, if the flight is made primarily to carry passengers, whose presence does not contribute to the aircraft or agency's mission (perhaps to carry an agency official or a governor to a business meeting), then it is probably a commercial purpose and therefore not a public aircraft operation. $^{21}$ If the operating entity certifies to the FAA that the flight is necessary for emergency or humanitarian purposes (such as, in the governor's case, when the aircraft is used to fly the governor to respond to a natural or man-made disaster), then the flight may still qualify as a public aircraft operation. In any case, the FAA retains its jurisdiction over that aircraft's operations in the national airspace (the general operating rules). ${ }^{22}$

When one unit of a governmental entity (such as the Federal Bureau of Investigation) provides air transportation services to the personnel of another unit of the federal government (perhaps the Department of Homeland Security) in response to a particular event or situation, the mere carriage of passengers should not render the flight a commercial operation. That, however, has not always been clear, as became evident when the FAA proposed an AC attempting to define what is and is not a public aircraft operation under the circumstances just described. ${ }^{23}$ That AC has since been amended to clarify the meaning of the rules governing public aircraft operations, and reportedly to close a loophole in the older AC that allowed

17 See id.

1849 U.S.C. $\S 40102$ (2012).

19 See 14 C.F.R. $\S 1.1$.

20 See Federal Aviation Administration, Public Aircraft Operations, Advisory Circular 00-1.1A, Feb. 12, 2014.

$21 \quad I d$.

22 See 14 C.F.R. $\$ 91$.

23 See Federal Aviation Administration, supra note 20. 
the FAA to issue Certificates of Waiver or Authorization (COAs) for unmanned aircraft operations premised on the "public aircraft" exception. ${ }^{24}$ The FAA did not (and this was before FMRA was passed) permit commercial UAS operations under the authority of a COA; but public aircraft operated by entities such as public universities could qualify for UAS COAs, even though their operations were arguably commercial under the FARs. ${ }^{25}$ The impact of this amendment to AC 00-1.1 will be addressed below.

The third category of aircraft is "civil," which includes everything that is not a public or state aircraft operation. A public aircraft can be involved in a public purpose on one flight and a commercial purpose an hour later, and thereby lose that public aircraft status for the second flight. The "public aircraft operation" is thus determined by the nature of the flight, and does not attach to the aircraft itself. All civil aircraft operations must be conducted in strict observance of all relevant FARs, which, at a minimum means pilot certification, aircraft type and manufacturing certificates, airworthiness certificates, registration, identification, and compliance with the general operating rules. Anyone seeking to operate an aircraft of any type, including remotely piloted aircraft, in U.S. domestic airspace, as well as international airspace wherein the FAA provides air navigations services (Flight Information Regions or FIRs) is obligated to be familiar with and obey a labyrinth of regulations pertaining to aviation. ${ }^{26}$ Penalties for failure to comply include civil fines, forfeitures of property, loss of privileges and even criminal charges. ${ }^{27}$

In 1995, Congress passed Public Law 103-411, the Independent Safety Board Act Amendments of 1994, in which the definition of the term "public aircraft" was amended to exclude any government-owned aircraft engaged in carrying persons or property for commercial purposes, but provided exceptions to the broad rule when the operation had certain purposes and the personnel being transported were essential to the mission of certain operations. ${ }^{28}$ AC 00-1.1, dated April 19, 1995, was the FAA's attempt to interpret the statutory definition of "public aircraft" as it pertains to operations where the federal government contracts with state or local governmental entities to provide aviation services in situations where the federal government has jurisdiction (such as forest fires in national parks or

$24 \quad I d$.

25 See Federal Aviation Administration, Unmanned Aircraft Systems, National Policy N 8900.227 (July 13, 2013).

26 See 49 U.S.C. $\$ 40103$; see also 14 C.F.R. $\$ 91$.

27 14 C.F.R. $\$ \$ 13.13-13.25$.

2849 U.S.C. $\S 40102(\mathrm{a})(41)$ (2012). 
other natural disasters requiring federal intervention), but does not have sufficient assets available to respond. Under those circumstances, the federal government entity may enter into an arrangement with the state or local government entity in which the land lies to provide assistance. ${ }^{29}$ The same issues arise when any governmental entity, which otherwise enjoys the protection and regulatory exemptions of public aircraft status, contracts with a private entity or individual to provide those support services. The question in these circumstances is whether such an operation would qualify for the veil of liability protection that is enjoyed by the governmental entity for which the services are provided. However, there is no language in the public aircraft statute that requires that the public aircraft operation be noncommercial. ${ }^{30}$

The continued controversies and uncertainties generated by the earlier interpretation motivated the FAA to issue a new policy statement clarifying AC 00-1.1 and soliciting comments. ${ }^{31}$ The revised policy states:

Public aircraft status is not an "automatic" status granted by the existence of a contract between a civil operator and a government agency.

The FAA considers ALL contracted operations to be civil aircraft operations, unless:

The contracting government entity provides the operator with a written declaration (from the contracting officer or higher-level official) of public aircraft status for designated, qualified flights;

The contracted operator notifies the FAA Flight Standards District Office (FSDO) having oversight of the operator (or the operation, as appropriate) that it has contracted with a government entity to conduct "eligible" public aircraft operations;

The contracted operator submits the written declaration to the FSDO with jurisdiction having oversight;

The flight(s) in question are determined to be legitimate public aircraft operations under the terms of the statute; and

The declaration is made in advance of the proposed public aircraft flight.

To implement this policy and collect data, the FSDO having oversight of the contracted operator will record receipt of these declarations by electronic means.

Contracted government entities are cautioned that public aircraft

3049 U.S.C. $\S 40102$ (a)(41) (2012).

31 See Federal Aviation Administration, supra note 20. 
operations performed by civil operators create a significant transfer of liability to the contracting government entity, and that FAA oversight ceases. $^{32}$

Civil operators are cautioned that unless there is a declaration of public aircraft status, all operations must be conducted in accordance with all applicable civil aviation regulations, and that the FAA retains oversight and enforcement authority for any deviation from the provisions of Title 14 of the Code of Federal Regulations. ${ }^{33}$ Operators are also cautioned that it is their responsibility to refuse a contract to perform operations that violate Title 14 if they cannot ensure that the government entity offering the contract has declared that operation as a public aircraft operation and that such flight meets the public aircraft eligibility requirements as outlined in the statute. ${ }^{34}$

Thus, the FAA has interpreted the commercial purposes prohibition found in the statute to prohibit any form of reimbursement to government entities for public aircraft operations, so that reimbursement for public aircraft operation is strictly limited to one set of circumstances defined in the statute. ${ }^{35}$ The AC expands the definition of the term "commercial" from "transportation of persons or property for compensation or hire" to include any situation where the government is reimbursed for the flight. Specifically, "[t]he statutory prohibition on commercial purposes prevents a government entity from getting paid or reimbursed to operate a public aircraft operation, not for paying for contracted services." ${ }^{36}$

\section{How Does THE CURRENT POLICY APPLY TO PUBLIC AIRCRAFT UAS OPERATIONS?}

What is the significance of this proposed policy interpretation as it impacts operations of unmanned and remotely piloted aircraft in the United States? First, it must be noted that an FAA AC is an interpretation of rules or statutes by the FAA, and is not itself a statute or regulation. It is thus unenforceable when standing alone, and is subject to reinterpretation, reconsideration, or challenge. ${ }^{37}$ That being said, public aircraft are not exempt from the registration requirements, ${ }^{38}$ and U.S.-registered public aircraft are not required to have an airworthiness certificate while operating

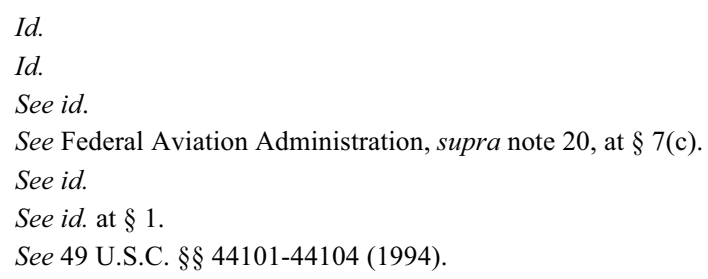


in domestic airspace, but if they enter international airspace or the airspace of another country they must be so registered and certificated. ${ }^{39}$ Numerous federal agencies, other than the Department of Defense and Customs and Border Protection, and state and local governments, including state colleges and universities, own and operate a variety of unmanned aircraft. These devices vary in size from hand launched aircraft, similar to recreational radio-controlled model airplanes that weigh less than five pounds, to highaltitude, long endurance (HALE) surveillance or remote sensing platforms, whose dimensions and performance characteristics are similar to commercial passenger aircraft. ${ }^{40}$ More recently, small, commercially available and relatively inexpensive multi-rotor, remotely piloted aircraft have become ubiquitous, and potentially a nuisance to the general public if misused or abused, as well as presenting a major headache for the FAA. ${ }^{41}$

FAA policy as of July 29, 2014, stated that these "public" aircraft cannot operate outside of segregated or restricted airspace without the permission of the FAA, secured by a document known as a Certificate of Waiver or Authorization. ${ }^{42}$ This National Policy statement has not been reissued or superseded, but the FAA's website still lists a 2007 Federal Register Notice, entitled "Unmanned Aircraft Operations in the National Airspace System" as the current statement of FAA policy with regard to public aircraft. ${ }^{43}$ The policy stated therein is essentially the same as the National Policy set forth in N 8900.227. The issuance of a COA, again according to current FAA policy, requires an exhaustive safety and operational review of all the details of the proposed flight or flights, and may result in the granting of certain waivers of pertinent sections of 14 C.F.R. Part 91, the General Operating and Flight Rules of the FARs. ${ }^{44}$ The FAA's policy also requires that COA applications include detailed airworthiness statements, as well as assurances that the pilots (operators) of the systems and the visual observers that are usually required be certificated

39 Convention on International Civil Aviation, July 2005, Annex 2, I.C.A.O., available at http:// www.icao.int/Meetings/anconf12/Document\%20Archive/an02_cons\%5B1\%5D.pdf.

40 DOUglas Marshall, ISSUES in AViation LAW AND Policy: INTERNATIONAL REgulation OF UNMANNED AIRCRAFT OPERATIONS IN OFFSHORE AND INTERNATIONAL AIRSPACE (International Aviation Law Institute) (Autumn 2008).

41 See Nick Wingfield, Now, Anyone Can Buy A Drone. Heaven Help Us., N.Y. TimEs (Nov. 26, 2014), available at http://www.nytimes.com/2014/11/27/technology/personaltech/as-drones-swoopabove-skies-thrill-seeking-stunts-elicit-safety-concerns.html.

42 FAA National Policy N 8900.227 Effective date 7/30/13, Cancellation Date 7/30/14.

43 See Federal Aviation Administration, Unmanned Aircraft Operations in the National Airspace System, FAA.GOV (Feb. 6, 2007), https://www.faa.gov/uas/media/frnotice_uas.pdf.

44 See Federal Aviation Administration, Certificates of Waiver or Authorization, FAA.gOv (Nov. 14, 2014, 1:20 PM), https://www.faa.gov/about/office_org/headquarters_offices/ato/serviceunits/ systemops/aaim/organizations/uas/coa. 
and medically qualified. ${ }^{45}$ The alternative for the public operator is to pursue the same operational permit as the civil sector, which is a Special Airworthiness Certificate in the Experimental Category, a Special Class Certificate under 14 C.F.R. $\S 21.17$ (b), or an exemption under $\S 333$ of the FMRA. ${ }^{46}$ The COA process can be long and potentially expensive, but has been the most expedient for public aircraft operators.

Thus, the essence of the FAA policy regarding remotely piloted aircraft is that all users of the national airspace must comply with all of the applicable FARs, not just the general operating and flight rules in 14 C.F.R. Part 91, and that federal, state and local governmental agencies must certify (or self-certify) their aircraft and pilots as if they were civilian operators.

The law discussed thus far supports the proposition that the Federal Aviation Regulations generally do not apply to public aircraft, (although their pilots must comply with the general operating rules so that there are no compromises to safety in the air). However, the FAA has declared by guidance documents and policy statements that public aircraft and their pilots must be certificated, or something equivalent thereto, to qualify for the Certificate of Waiver or Authorization that the FAA states is a requirement for UAS operations to take place outside of protected or segregated airspace. Some public agencies (particularly law enforcement organizations) pushed back against those restrictions and challenged the FAA policy as unsupported by law and therefore unenforceable. One result

$45 \quad I d$.

46 FMRA Section 333 reads:

SEC. 333. SPECIAL RULES FOR CERTAIN UNMANNED AIRCRAFT SYSTEMS.

(a) IN GENERAL - Notwithstanding any other requirement of this subtitle, and not later than 180 days after the date of enactment of this Act, the Secretary of Transportation shall determine if certain unmanned aircraft systems may operate safely in the national airspace system before completion of the plan and rule- making required by section 332 of this Act or the guidance required by section 334 of this Act.

(b) ASSESSMENT OF UNMANNED AIRCRAFT SYSTEMS.-In making the determination under subsection (a), the Secretary shall determine, at a minimum-

(1) which types of unmanned aircraft systems, if any, as a result of their size, weight, speed, operational capability, proximity to airports and populated areas, and operation within visual line of sight do not create a hazard to users of the national airspace system or the public or pose a threat to national security; and

(2) whether a certificate of waiver, certificate of authorization, or airworthiness certification under section 44704 of title 49, United States Code, is required for the operation of unmanned aircraft systems identified under paragraph (1).

(c) REQUIREMENTS FOR SAFE OPERATION. - If the Secretary determines under this section that certain unmanned aircraft systems may operate safely in the national airspace system, the Secretary shall establish requirements for the safe operation of such aircraft systems in the national airspace system. FAA Modernization and Reform Act of 2012, Pub. L. No. 112-95, § 333, 126 Stat. 11 (2012). 
of this effort was language in the FMRA specifically addressing public unmanned aircraft systems. ${ }^{47}$ FMRA reads, in part:

(c) AGREEMENTS WITH GOVERNMENT AGENCIES. -

(1) IN GENERAL.-Not later than 90 days after the date of enactment of this Act, the Secretary shall enter into agreements with appropriate government agencies to simplify the process for issuing certificates of waiver or authorization with respect to applications seeking authorization to operate public unmanned aircraft systems in the national airspace system.

(2) CONTENTS.-The agreements shall-

(A) with respect to an application described in paragraph (1) -

(i) provide for an expedited review of the application;

(ii) require a decision by the Administrator on approval or disapproval within 60 business days of the date of submission of the application; and

(iii) allow for an expedited appeal if the application is disapproved;

(B) allow for a one-time approval of similar operations carried out during a fixed period of time; and

(C) allow a government public safety agency to operate unmanned aircraft weighing 4.4 pounds or less, if operated-

(i) within the line of sight of the operator;

(ii) less than 400 feet above the ground;

(iii) during daylight conditions;

(iv) within Class G airspace; and

(v) outside of 5 statute miles from any airport, heliport, seaplane base, spaceport, or other location with aviation activities.

If public aircraft operations are, by statute, exempt from the FARs, except for the general operating rules, then the FAA's authority over public aircraft operations with regard to airworthiness, certification, and operator qualifications is debatable. The statutory mandate to the FAA merely sets the broad parameters for public safety agency operations, without authorizing the FAA to require more specific qualifications of the systems and operators in order to obtain a COA. The FAA has been directed to enter into agreements with the appropriate government agencies to simplify the process for issuing COAs. ${ }^{48}$ As stated above, an aircraft used exclusively

47 FAA Modernization and Reform Act of 2012, Pub. L. No. 112-95, § 334, 126 Stat. 11, 76-77 (codified as amended at 49 U.S.C. $§ 40101$ (2012)).

48 MARSHALL, supra note 40. 
for the U.S. government is considered a "public aircraft," provided it is not a government-owned aircraft transporting passengers or operating for commercial purposes. A public aircraft is not subject to any FARs regarding aircraft certification, maintenance, and pilot certification, but must comply with the general operating rules found in 14 C.F.R. Part 91. If an agency transports passengers on a government-owned aircraft or uses that aircraft for commercial purposes, the agency must comply with all FARs applicable to civil aircraft. ${ }^{49}$

Before the enactment of the FMRA, the COA process and the forms that must be submitted to apply for the waiver represented the sole mechanism for a qualified organization or individual to gain approval for an "aviation event" (other than parachuting) such as an airshow or air race, and the instructions that accompany the form clearly state that it is for that purpose only. ${ }^{50}$ The waivers sought under this process refer to 14 C.F.R. Parts 61 and 91, the pilot certification, and general operating rules sections of the Code of Federal Regulations. In other words, the regulators are most concerned that participants in such aviation events are appropriately qualified to operate the aircraft that are involved, and that the applicants and event organizers have taken necessary measures to protect persons and property on the ground and do not interfere with other aviation activities in the area.

Thus, there is some inherent ambiguity in the FAA's policy requiring a public UAS user to meet all of the COA qualification standards, and not just those that require compliance with the relevant general operating rules, because arguably, the necessity of even participating in the COA process is not clear if the applicant is not staging aviation events such as airshows or air races.

Another source of uncertainty is the policy that underlies the distinction between public aircraft used for specific governmental purposes and merely the carrying of passengers. Whether an operation may be considered public is determined on a flight-by-flight basis under the terms of the statutes; aircraft ownership, identity of operator, the purpose of the flight and the persons on board the aircraft are factors in determining whether the operation qualifies for public aircraft status, or is being operated for commercial purposes. ${ }^{51}$ What is clear, from examining the history of the statutes and the policies, is that the intent is to separate operations that are solely conducted for the purpose of carrying passengers

4941 C.F.R. $\$ 102-33.165$ (2014).

50 FAA Form 7711-2, Application for Certificate of Waiver or Authorization, available at http:// www.faa.gov/documentlibrary/media/form/faa7711-2.pdf.

5149 U.S.C. $§ 40102$ (2012); 49 U.S.C. $§ 40125$ (2012). 
from those that have persons on board but whose presence is required to perform the mission of the flight, or who are associated with the performance of the aircraft operation. Examples given in the policies include aircraft maintenance personnel who may accompany the aircraft to a remote location so as to service and maintain the aircraft away from its home base.

The phrase "for commercial purposes" means for compensation or hire. It can also include cost reimbursement between units of government (pursuant to the "imminent danger" exception). No profit is required. However, the transfer of funds from one element of government to another is not a commercial transaction. If the governmental entity declares that there is an imminent danger of loss of life or substantial property, the carrying of passengers alone can also be a protected activity that does not lose its public designation so as to become a "civil" operation. ${ }^{52}$

If operations for a commercial purpose provide an exception to public aircraft designation, and "commercial purpose" means for hire or compensation, is the underlying intent to protect passengers on board, and if so, does that then apply to remotely piloted aircraft? History suggests that the safety concern expressed in the policy is the carriage of passengers, or transporting property or "passengers" for compensation or hire. The unifying characteristic shared by the governmental functions listed in the statute is that they each involve the carriage of persons as part of a mission for which the use of an aircraft is necessary.

As previously stated, FAA policy is that public aircraft status is not an "automatic" status granted by the existence of a contract between a civil operator and a government agency. The FAA considers all contracted operations to be civil aircraft operations, unless:

1. The contracting government entity provides the operator with a written declaration (from the contracting officer or higher-level official) of public aircraft status for designated, qualified flights;

2. The contracted operator notifies the FAA Flight Standards District Office (FSDO) having oversight of the operator (or the operation, as appropriate) that it has contracted with a government entity to conduct "eligible" public aircraft operations;

3. The contracted operator submits the written declaration to the FSDO with jurisdiction having oversight;

4. The flight(s) in question are determined to be legitimate public aircraft operations under the terms of the statute; and

5. The declaration is made in advance of the proposed public aircraft 
flight.

\section{DOES “AERONAUTICAL RESEARCH” INCLUDE RESEARCH EMPLOYING UAS?}

In March of 2013, the UAS Integration Office (AFS-80) solicited an opinion from the office of FAA Chief Counsel for International Law, Legislation and Regulations (AGC-200) requesting clarification of the terms "commercial purpose" and "governmental function" under 49 U.S.C. $\S 40125(\mathrm{a})(1)$ and (2) with regard to UAS operations by public entities. More specifically, the UAS Integration Office was seeking guidance on the use of UAS by public universities for conducting aeronautical research.

49 U.S.C. $§ 40125$ (a)(1)-(3) states:

(a) Definitions.- - In this section, the following definitions apply:

(1) Commercial purposes.-The term "commercial purposes" means the transportation of persons or property for compensation or hire, but does not include the operation of an aircraft by the armed forces for reimbursement when that reimbursement is required by any Federal statute, regulation, or directive, in effect on November 1, 1999, or by one government on behalf of another government under a cost reimbursement agreement if the government on whose behalf the operation is conducted certifies to the Administrator of the Federal Aviation Administration that the operation is necessary to respond to a significant and imminent threat to life or property (including natural resources) and that no service by a private operator is reasonably available to meet the threat.

(2) Governmental function.-The term "governmental function" means an activity undertaken by a government, such as national defense, intelligence missions, firefighting, search and rescue, law enforcement (including transport of prisoners, detainees, and illegal aliens), aero-nautical research, or biological or geological resource management.

(3) Qualified non-crewmember.-The term "qualified noncrewmember" means an individual, other than a member of the crew, aboard an aircraft.

(B) whose presence is required to perform, or is associated with the performance of, a governmental function.

AGC-200 responded to this request with an internal memorandum dated June 13, 2014. ${ }^{53}$ This memorandum concludes that the referenced

53 Memorandum from Mark W. Bury, Assistant Chief Counsel for International Law, Legislation and Regulations, FAA, to James Williams, Manager, UAS Integration Office, FAA, (June 13, 2014). 
statute would significantly restrict UAS operations by state (public) universities or colleges (or presumably any public school at any level) for two reasons. First, the memorandum argues that the "aeronautical research" provision under the "governmental function" definition does not include just any research. Rather, this interpretation would limit aeronautical research solely to the development of the aircraft or its systems. Second, the FAA contends that the provision of the statute that restricts public aircraft operation status when the aircraft is used for "commercial purposes" should be read broadly, and effectively prohibits private research sponsors from receiving any benefits from UAS research, or universities from receiving any form or reimbursement or payment to operate UAS.

Predictably, the memorandum sparked an outcry from public universities around the country, especially those that had been granted UAS Test Range status under Section 332 of the FMRA. ${ }^{54}$

A follow-up memorandum dated July 3, 2014, ${ }^{55}$ was issued in response to questions AGC-200 had received regarding the scope of the first memorandum. Here, the Assistant Chief Counsel modified her earlier opinion of when research would constitute a "government function" under the statute. The memorandum confirms that aeronautical research is a government function. Research utilizing UAS that goes beyond just analyzing the aircraft or its systems can also satisfy the requirements of a public aircraft operation if that "research project fulfills another governmental function under the statute." ${ }^{56}$ The memorandum goes on to suggest that, because the statutory language is not exclusive, each proposed research activity would have to be presented to and assessed by the FAA, which would make a determination on whether the research supports a "core governmental function." Thus, any proposed research using UAS in the national airspace would have to be reviewed on a case-by-case basis by the FAA, giving the FAA authority to determine if a particular research proposal is a "legitimate" research subject, a role that is outside of the scope the FAA's authority.

While the issue of what is and is not "aeronautical research" and whether said research performs a "governmental function" could be the topic of an entirely separate article, operations of UAS as public aircraft are not dependent on either aeronautical research or a governmental function exception. A review of the historic development of the public aircraft statute is instructive in demonstrating why that is so.

$\begin{array}{ll}54 & I d \\ 55 & I d \\ 56 & I d\end{array}$


Prior to 1994, public aircraft were defined simply as "any aircraft used exclusively in the service of any government or of any political subdivision thereof, including the government of any State, Territory, or possession of the United States, or the District of Columbia, but not including any government-owned aircraft engaged in carrying persons or property for commercial purposes." ${ }^{" 57}$ For purposes of this paragraph, "used exclusively in the service of" means, for other than the federal government, an aircraft which is owned and operated by a governmental entity for other than commercial purposes or which is exclusively leased by such governmental entity for not less than ninety continuous days. ${ }^{58}$

In 1994, the statutory definition of public aircraft was amended to narrow the scope of public aircraft operations allowed by public entities. The impetus for the amendment was a fatal accident in 1993 involving the crash of a public aircraft operated by the State of South Dakota that killed Governor George Mickelson and seven others. ${ }^{59}$ The ensuing investigation revealed that after an earlier incident with similar circumstances the National Transportation Safety Board (NTSB) offered specific safety recommendations to the FAA. Though the FAA did not adopt those recommendations, South Dakota Senator Larry Pressler was troubled to learn that even if the FAA had adopted the NTSB recommendations, the State, as a public aircraft operator, would have no obligation to comply with them. $^{60}$ In contrast, compliance by a civil aircraft would have been mandatory. Accordingly, on May 12, 1994, Senator Pressler sought to narrow the arena in which a public aircraft could operate and remain exempt from the FARs. His purpose was "to mandate that FAA safety regulations, directives and orders issued for civil aircraft be made applicable to all government-owned, nonmilitary aircraft engaged in passenger transport." $" 61$ In short, he felt that passengers on board government-operated aircraft should enjoy the same level of safety requirements as those onboard civil aircraft. The amendments were adopted and a new statutory definition of public aircraft followed. ${ }^{62}$

This new language did not make any significant changes regarding the

57 See FAA Advisory Circular 00-1.1, Government Aircraft Operations (Apr. 19, 1995), available at http://www.faa.gov/documentLibrary/media/Advisory_Circular/AC\%2000-1.1.pdf [hereinafter Ad-visory Circular 00-1.1].

58 See 49 U.S.C. $\S 40102(a)(37)$ (1994) (amended 2012) for the definition of public aircraft.

59140 CONG. REC. 58 (1994); Advisory Circular 00-1.1.

60140 CONG. REC. 58 (1994).

61 Id.; see also Proposed Advisory Circular on Government Aircraft Operations, 60 Fed. Reg. 5237, 5239 (Jan. 26, 1995).

62 Independent Safety Board Act Amendments of 1994, Pub. L. No. 103-411, 108 Stat. 4236 (codified as amended at 49 U.S.C.A. § 40102 (1994)). 
transportation of cargo. Carriage of property continued to be permitted aboard a public aircraft, unless that carriage was solely for "commercial purposes." Passengers could not be transported aboard public aircraft unless they were crewmembers. However, an exception was made for passengers on board whose presence was required to perform a "governmental function." One of the listed examples of a governmental function was "aeronautical research." "63 Importantly, any analysis of whether the governmental function or aeronautical research exceptions were applicable could occur only after establishing that passengers were being carried.

Section 40102(a)(37) was again amended in 2000. Section 702 of the Wendell H. Ford Aviation Investment and Reform Act for the 21st Century ${ }^{64}$ rephrased the definition of public aircraft. Section 40125 was added to complete the new definition of public aircraft. ${ }^{65} \mathrm{With}$ regard to the intent of this change, the House Committee Report ${ }^{66}$ clearly explained that the intent was:

[S]olely to replace old convoluted language (laden with multiple negatives) with positive language that states existing law in terms that are readily understood by both the nation's aviation community and the general public. Nothing in $\S 702$ should be interpreted as a change in current public policy relating to public aircraft. ${ }^{67}$

With respect to the transportation of property, the House report reconfirmed that the earlier 1993 amendment, not changed by $\S 702$, was directed at the carriage of cargo, "[w]ith respect to the transportation of cargo, the law continued to state that a government aircraft that transports property is a public aircraft unless it transports that property "for commercial purposes." 68 The term "property" referred to cargo and the statute was intended to prohibit public aircraft from transporting for commercial purposes any cargo on board the aircraft. ${ }^{69}$

Nowhere in the history of public aircraft operations is any reference to the operation of UAS to be found. This is no surprise. The statutes, since their inception, were focused on the transportation of cargo or passengers.

6349 U.S.C. $\S 40102$.

64 Wendell H. Ford Aviation Investment and Reform Act for the 21st Century, Pub. L. No. 106181, 114 Stat. 61 (codified as amended at 49 U.S.C. $\S 40101(2000)$ ).

6529 U.S.C. $\S 40125$ (2005).

66 H.R. REP. NO. 106-167 (1999). This accompanied H.R. 1000, which was the house bill that was to become Wendell H. Ford Aviation Investment and Reform Act for the 21 st Century the following year.

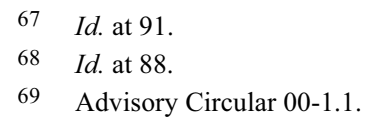


UAS by their nature do not involve passengers or even crewmembers on board a UAS aircraft. Before pursuing any discussion of whether there is a governmental function behind the flight, there first must be a determination that a passenger is on board the aircraft to serve such a function. The passenger must be serving a governmental function, not the aircraft itself. In light of the history of public aircraft legislation, as well as the FAA's own policy statements, the interpretation offered by the subject FAA memoranda is unsupported by established law or policy.

What does the foregoing mean for other "public aircraft" users and operators? Is a governmental agency desiring to operate a remotely piloted aircraft legally compelled to apply for a Certificate of Waiver or Authorization and to provide to the FAA comprehensive statements of airworthiness and pilot qualifications before it can conduct operations in the national airspace? In other words, can the FAA require public entities to comply with the non-operating conditions imposed in the terms of COAs? The FAA policy is that COAs are not required for operations conducted wholly within an active Restricted, Prohibited, or Warning Area airspace when operating with permission from the appropriate authority or the agency or entity utilizing that airspace..$^{70}$ There is nothing in the United States Code or the current regulations that establishes that distinction, or creates an exception to the general public aircraft rule for operators of unmanned aircraft. And there is nothing in those precedents that should prohibit public entities, public universities, or other governmental agencies from accepting reimbursement from private entities or private contractors for the costs of permitting research, testing, and training of unmanned aircraft systems and their operators within the confines of COAs operated by those entities. Nor should those public entities acting under the authority of the test ranges that have been mandated by Congressional action pursuant to the FAA Modernization and Reform Act of 2012 be prohibited from accepting compensation or reimbursement for the services that they provide. Indeed, the business case for keeping those test ranges open and viable fails without allowing for some reasonable level of cost recovery by those entities.

And, equally important, there is no precedent for declaring digital images or electronic data gathered by a remotely piloted aircraft to be equivalent to the traditional definition of cargo for purposes of defining a commercial operation that would remove such an operation from public aircraft status. 


\section{CONCLUSION}

In spite of a widely observed policy that declares that public aircraft operators are generally exempt from compliance with federal aviation regulations, except for the general operating rules, and that all public operators must obtain a Certificate of Waiver or Authorization before they can operate remotely piloted aircraft in the national airspace, there is little or no statutory or regulatory justification for that policy. It is therefore likely that a public entity could operate an unmanned aircraft in the national airspace without applying for a COA and in fact asking for no permission at all other than that which would ordinarily be required of a manned public aircraft operation pursuant to the general operating rules (assuming that the UAS is properly registered and carries identifying markings). Furthermore, there is no statutory or regulatory justification for the FAA policy prohibiting public entities from receiving reimbursement from contractors and vendors operating remotely piloted aircraft under the auspices of a COA or within the confines of one of the six congressionally authorized test ranges.

Without sound historical support or empirical data regarding safe operations of UAS, the largest majority of which weigh less than fifty-five pounds, and are no larger than a radio-controlled aircraft flown for recreational purposes, there is no practical justification for imposing public aircraft rules and restrictions with regard to commercial purposes on RPAs operated by or under the authority of any appropriately qualified public entity. In fact, the current policy may well be a deterrent to innovation and humanitarian uses of small remotely piloted aircraft in the U.S. national airspace.

For the purpose of advancing the intent of the 112th Congress in promulgating specific requirements for the integration of unmanned aircraft systems into the national airspace, and with specific attention to public aircraft operations and full utilization of the six UAS Test Ranges, the FAA should be encouraged to revisit its policies with regard to the requirements for a COA to conduct public aircraft operations with UAS. In addition, the FAA's prohibition against public entities receiving cost reimbursements for the research and services they provide to the larger community, as well as to the FAA, is against public policy, is contrary to the intent of Congress, and should be abandoned as an unnecessary impediment to critical research supporting the integration of UAS into the national airspace. 